\title{
ANALISIS DAN PERANCANGAN APLIKASI INVENTORI BERBASISKAN RFID PADA PT. ABC
}

\author{
Herwin; Richard Saputra \\ Jurusan Teknik Informatika, Fakultas Ilmu Komputer, Bina Nusantara University \\ Jln. Kemanggisan Ilir III No 45, Kemanggisan, Palmerah, Jakarta Barat 11480 \\ herwin.pranata@yahoo.com; richard.saputra@gmail.com
}

\begin{abstract}
The purpose of this research is to reduce the damaged material, applying the concept of FIFO for retrieval of row materials, and accelerate the search and also to simplify the detection of raw materials. Software development method used involves three main parts namely the method of analysis, design and literature. Analysis methods including survey of the running system, an analysis of survey findings, identify information needs, identify system requirenments. The design method approach to Unified Modelling Language (UML). The results is an inventory application that uses Radio Frequency Identification (RFID) tags as a replacement label where RFID tags can store data. Conslusions from this research is minimizing the company's financial losses due to storage of raw materials and minimizing time to search raw materials using RFID that also can provide actual and accurate information for the company.
\end{abstract}

Keywords: raw materials, inventory, radio frequency identification.

\begin{abstract}
ABSTRAK
Tujuan dari penelitian ini adalah mengurangi bahan baku yang rusak, menerapkan konsep FIFO untuk pengambilan bahan baku, dan mempercepat pencarian serta mempermudah pendeteksian bahan baku. Metode pengembangan piranti lunak yang digunakan meliputi tiga bagian pokok yaitu metode analisa, perancangan dan studi pustaka. Metode analisis meliputi survei atas sistem yang sedang berjalan, analisis terhadap temuan survei, identifikasi kebutuhan informasi, identifikasi persyaratan sistem. Metode perancangan menggunakan pendekatan Unified Modelling Language (UML). Hasil penelitian adalah sebuah aplikasi inventori yang menggunakan tag Radio Frequency Identification (RFID) sebagai pengganti label dimana tag RFID dapat menyimpan data. Simpulan dari penelitian ini adalah meminimalisasikan kerugian finansial perusahaan akibat penyimpanan bahan baku yang kurang baik dan dapat mengefisienkan waktu pencarian bahan baku dengan menggunakan RFID yang dapat memberikan informasi yang aktual dan akurat bagi perusahaan.
\end{abstract}

Kata kunci: bahan baku, inventori, radio frequency identification 


\section{PENDAHULUAN}

\section{Latar Belakang}

Sesuai amanat Garis-garis Besar Haluan Negara (GBHN) tahun 1988 pembangunan sektor industri dalam pembangunan jangka panjang harus mampu membawa perubahan mendasar dalam struktur ekonomi Indonesia. Sasarannya adalah mewujudkan struktur ekonomi yang semakin kokoh dan seimbang dengan sektor industri yang maju. Pesatnya proses industrialisasi dalam pembangunan ekonomi harus ditunjang oleh perkembangan teknologi dan penerapannya dalam industri secara langsung. Perkembangan teknologi informasi telah berkembang dengan sangat pesat dan menawarkan berbagai macam keunggulan antara lain semuanya berbentuk digital sehingga lebih mudah, menarik, dan beragam.

Persaingan dunia bisnis dan kebutuhan pasar yang semakin kompleks, menuntut industri untuk memberikan yang terbaik kepada pelanggannya dengan menerapkan teknologi informasi yang mendukung industrinya. Perusahaan yang dapat menerapkan teknologi informasi yang paling sesuai akan beradaptasi dengan persaingan dunia bisnis saat ini.

Untuk menjadikan sebuah industri menjadi maju, dibutuhkan semua faktor-faktor yang mendukung proses sebuah industri. Salah satu faktor tersebut adalah tersedianya bahan baku dengan jumlah yang tepat untuk melakukan proses produksi. Bahan baku menjadi sangat penting karena tanpa bahan baku seluruh proses produksi akan berhenti secara keseluruhan. Banyak industri yang bahan bakunya sudah ada di gudang tetapi karena salah pencatatan mengakibatkan bahan baku terlalu lama di gudang dan menjadi rusak atau dianggap hilang.

Penggunaan teknologi Radio Frequency Identification (RFID) yaitu untuk mempermudah pencarian bahan baku. Teknologi RFID merupakan generasi kelanjutan dari barcode. RFID memungkinkan untuk mentransmisikan data tanpa harus berdekatan seperti barcode. Sebelum bahan baku disimpan ke gudang, terlebih dahulu dipasangkan tag RFID yang berisikan data tentang bahan baku tersebut. Saat petugas inventori ingin mencari bahan baku, mereka dapat menggunakan RFID reader untuk membantu pencarian. Selain itu penambahan database dalam sistem inventori akan memberikan kemudahan dalam hal pendataan dan memudahkan stock opname serta ketepatan pemesanan.

\section{Landasan Teori}

\section{Inventori}

Barang persediaan atau disebut inventori adalah barang-barang yang biasanya dapat dijumpai di gudang tertutup, lapangan, gudang terbuka, atau tempat-tempat penyimpanan, baik berupa bahan baku, barang setengah jadi, barang jadi, barang-barang untuk keperluan operasi, atau barang-barang untuk keperluan suatu proyek (Indrajit \& Djokopranto, 2003). Tidak peduli apakah perusahaan besar atau kecil, untuk pengadaan dan penyimpanan barang ini diperlukan biaya besar. Biasanya biaya yang paling besar adalah nilai inventori dan biaya penyimpanan. Biaya penyimpanan ini setiap tahun umumnya mencapai $20 \%-40 \%$ dari harga barang.

Untuk merubah bahan menjadi produksi jadi, maka hal ini akan memerlukan aktivitas pemindahan (movement) sekurang-kurangnya satu dari tiga elemen dasar sistem produksi yaitu: bahan baku, orang / pekerja, atau mesin dan peralatan produksi, bahan baku akan lebih sering dipindahkan dibandingkan dengan dua elemen dasar produksi lainnya (Wignjosoebroto, 2003). Pada beberapa kasus maka biaya untuk proses pemindahan bahan ini bisa mencapai 30\% sampai dengan $90 \%$ dari total biaya produksi dengan mengingat pemindahan bahan yang sedemikian besarnya, maka mereka 
yang bertanggung jawab usaha perencanaan dan perancangan tata letak pabrik akan lebih menekankan desainnya pada usaha-usaha memindahkan aktivitas-aktivitas pemindahan bahan pada saat proses produksi berlangsung.

\section{Radio Frequency Identification}

RFID adalah proses identifikasi seseorang atau objek dengan menggunakan frekuensi transmisi radio. RFID menggunakan frekuensi radio untuk membaca informasi dari sebuah device kecil yang disebut tag atau transponder (Transmitter + Responder). Tag RFID akan mengenali diri sendiri ketika mendeteksi sinyal dari device yang kompatibel, yaitu pembaca RFID (Micro-Reader).

\section{METODE}

\section{Analisis dan Pemecahan Masalah}

Pendataan bahan baku yang masuk ke gudang dengan benar dan penempatan pada posisi yang tepat menjadi rantai proses yang harus dijalankan dengan baik. Kesalahan pendataan bahan baku akan mengakibatkan kesalahan pada proses bisnis berikutnya mulai dari pencarian bahan baku yang tidak tepat, kesalahan produksi, hingga kerusakan bahan baku tersebut. Masalah-masalah yang menjadi studi kasus ini akan dibahas lebih lanjut.

Proses yang berjalan dengan benar akan menjadi harapan dari setiap perusahaan. Dengan kemajuan teknologi yang terus berkembang dengan pesat, hal tersebut tidak sulit untuk diwujudkan. Untuk itulah penerapan aplikasi dengan RFID yang akan memberikan layanan dengan efektifitas dan efisiensi yang lebih baik. Teknologi RFID akan membantu dalam proses bisnis di gudang mulai dari pemberian tag RFID pada bahan baku, hingga ke pencarian bahan baku yang lebih cepat. Ini didukung dengan menggunakan Reader RFID yang mengirimkan sinyal radio untuk membaca tag RFID tersebut.

Teknologi RFID semakin berkembang dan akan menggantikan penggunaan barcode ataupun label manual. Ini dikarenakan oleh sistem pada RFID yang menggunakan frekuensi radio dan tingkat keamanan yang lebih baik. Pada studi kasus ini pembuatan aplikasi dengan RFID akan memecahkan permasalahan proses bisnis yang sedang berjalan saat ini pada perusahaan PT. ABC.

\section{Proses Penerimaan Bahan Baku}

Saat bahan baku omput, bagian inventori akan menerima bahan baku yang omput. Bagian inventori akan mengeluarkan dokumen penerimaan bahan baku. Bagian inventori membandingkan dokumen penerimaan barang dan dokumen pemesanan bahan baku apakah sama atau tidak, kemudian memeriksa bahan baku yang komput apakah sesuai dengan pesanan. Bila bahan baku tidak sesuai dengan pesanan, maka bahan baku tersebut akan dipindahkan ke tempat sementara untuk dikembalikan. Bila bahan baku sesuai dengan pesanan maka bagian inventori akan mendata bahan baku yang omput, kemudian memberi label kepada bahan baku menggunakan tag RFID. Operator menggunakan komputer untuk melihat tempat yang masih kosong kemudian meletakan bahan baku sesuai dengan tempatnya. Bagian inventori meng-update data yang ada di dalam database. 


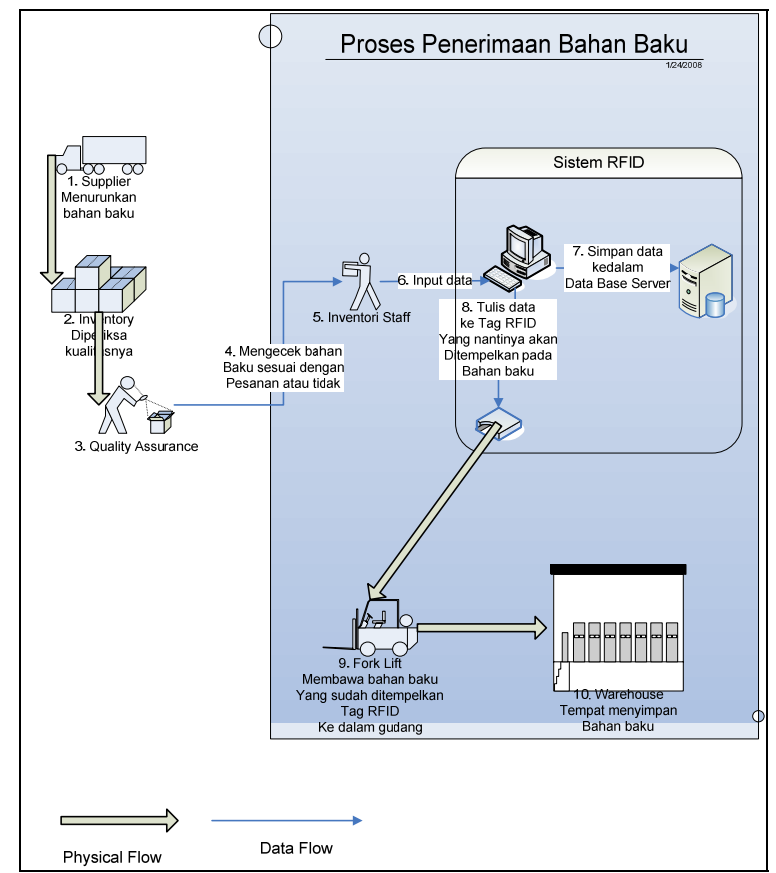

Gambar 1 Proses Penerimaan Bahan Baku

\section{Proses Produksi}

Bagian produksi mengalokasikan bahan baku yang ada untuk diproduksi. Bagian produksi akan mengeluarkan dokumen produksi. Bagian inventori yang menerima dokumen tersebut akan mencari dan mengambilkan bahan baku sesuai dengan permintaan dan mengupdate data dalam database. Setelah mendapatkan bahan baku, bagian produksi melepaskan tag RFID dari bahan baku dan memproses bahan baku lebih lanjut.

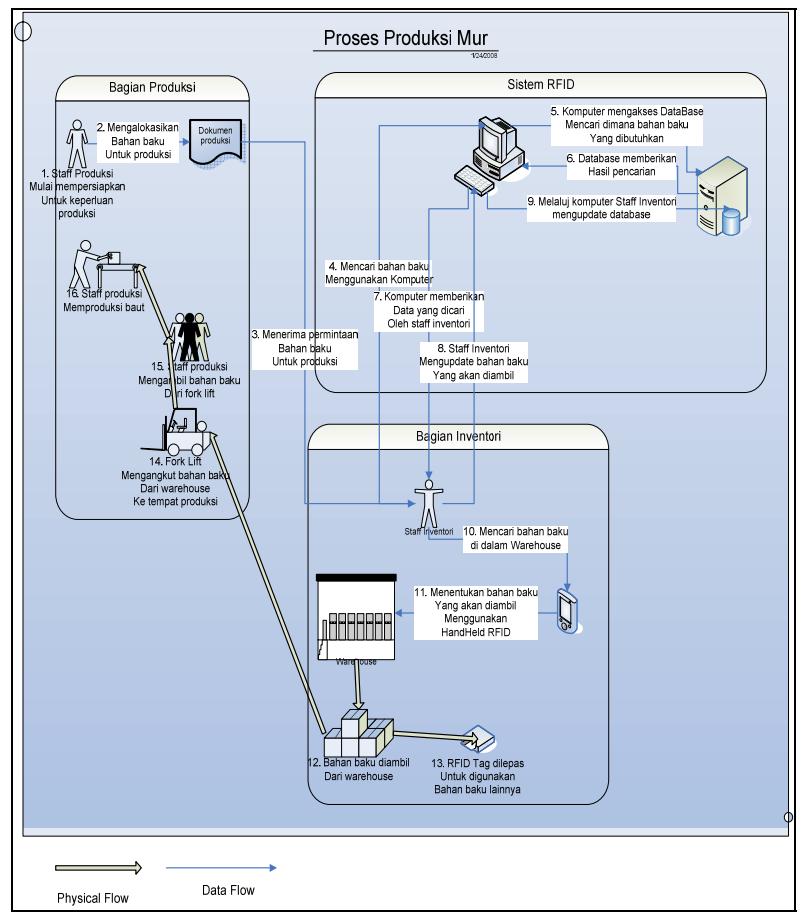

Gambar 2. Proses Produksi 


\section{Proses RFID}

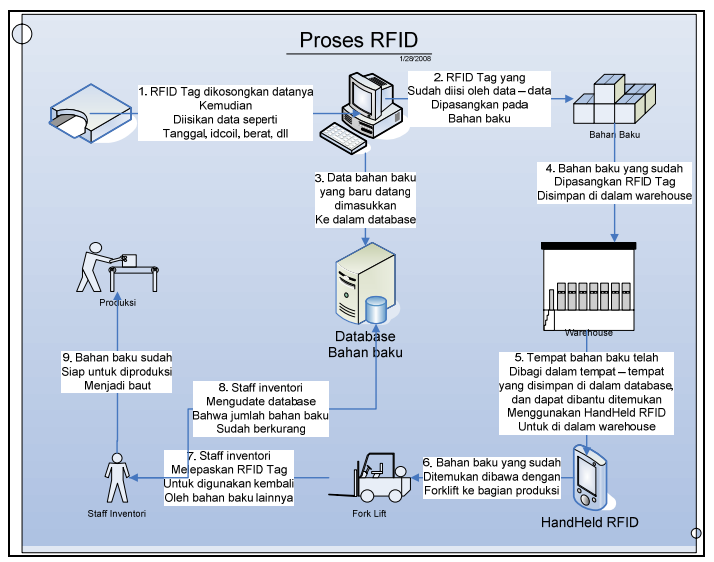

Gambar 3. Proses RFID

Proses RFID (seperti pada Gambar 3) yaitu: (1) tag RFID dikosongkan datanya kemudian diisikan data seperti tanggal, id, berat, dan lain-lain; (2) tag RFID yang sudah diisi oleh data-data dipasangkan pada bahan baku. Untuk satu bahan baku memiliki satu tag RFID; (3) data bahan baku yang baru datang dimasukkan ke dalam database; (4) bahan baku yang sudah dipasangkan Tag RFID disimpan di dalam warehouse; (5) tempat bahan baku telah dibagi dalam tempat-tempat yang disimpan di dalam database, dan dapat dibantu ditemukan menggunakan HandHeld RFID di warehouse; (6) bahan baku yang sudah ditemukan dibawa dengan forklift ke bagian produksi; (7) staf inventori melepaskan Tag RFID untuk digunakan kembali oleh bahan baku lainnya; (8) staf inventori mengudate database bahwa jumlah bahan baku sudah berkurang; (9) bahan baku sudah siap untuk diproduksi.

\section{Perancangan Layar (Storyboard) pada Solusi}

Rancangan layar yang dibuat disesuaikan dengan menu yang ada pada aplikasi, kebutuhan yang diperlukan dalam proses bisnis, dan menu yang mendukung pemecahan solusi. Berikut adalah rancangan layar dari aplikasi:

\section{Rancangan Layar Penerimaan Bahan Baku}

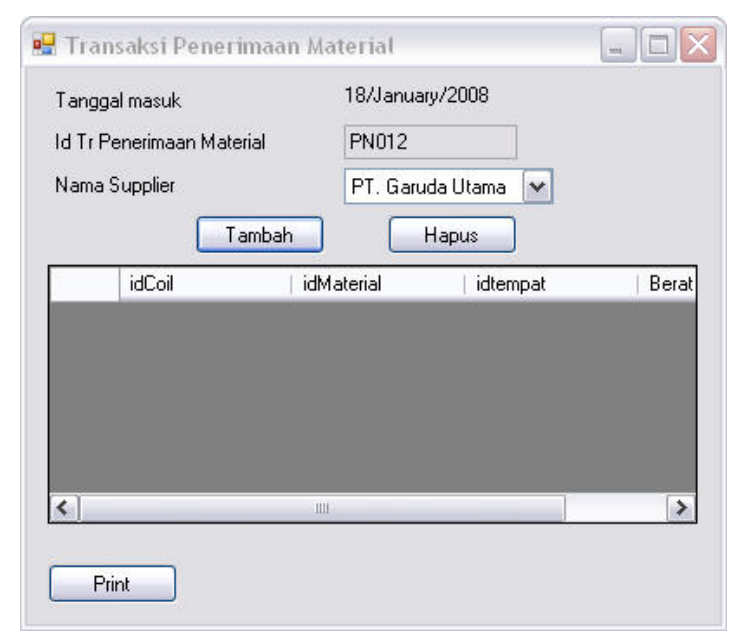

Gambar 4 Rancangan Layar Penerimaan Bahan Baku 
Form pada Gambar 4 menampilkan data penerimaan bahan baku yang tersimpan dalam tabel HistoryCoil. Untuk menambah data bahan baku, IdTrPenerimaanBahan baku akan otomatis terisi, pengguna menginput tanggal masuk dan nama supplier kemudian menekan tombol 'tambah'. Setelah menekan tombol 'tambah' akan ditampilkan Layar tag Bahan baku. Untuk menghapus data, pilih data yang akan dihapus kemudian tekan tombol 'hapus'.

\section{Rancangan Layar Detail Penerimaan Bahan Baku}

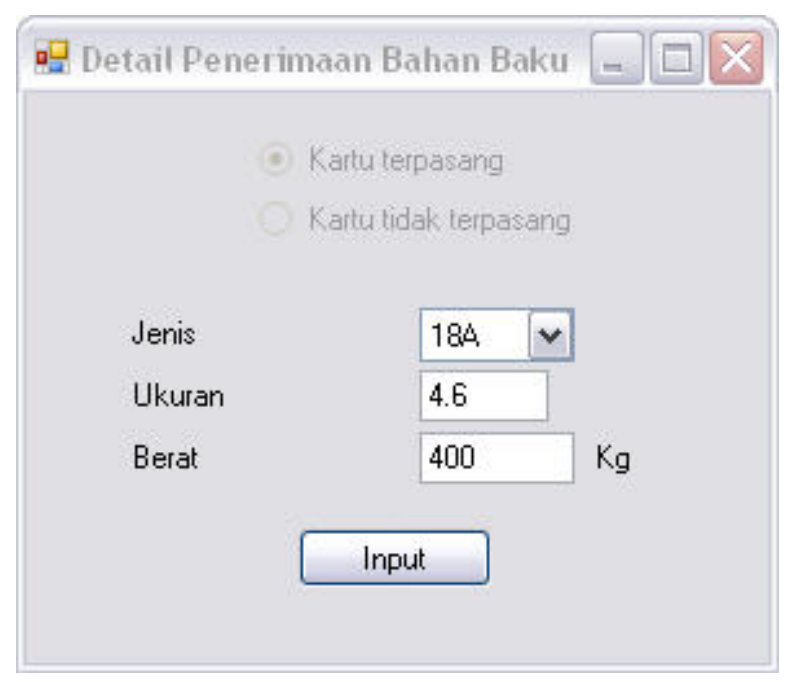

Gambar 5 Rancangan Layar Detail Penerimaan Bahan Baku

Form pada Gambar 5 ada setelah menambah data pada Layar Penerimaan Bahan baku. Form ini untuk mengisi data bahan baku dalam RFID Card, untuk jenis dapat dipilih, ukuran dan berat diisi oleh pengguna. Setelah selesai menginput data tekan tombol 'Input', kemudian form ini akan tertutup dan kembali ke form penerimaan bahan baku.

\section{Rancangan Layar Pengeluaran Bahan Baku}

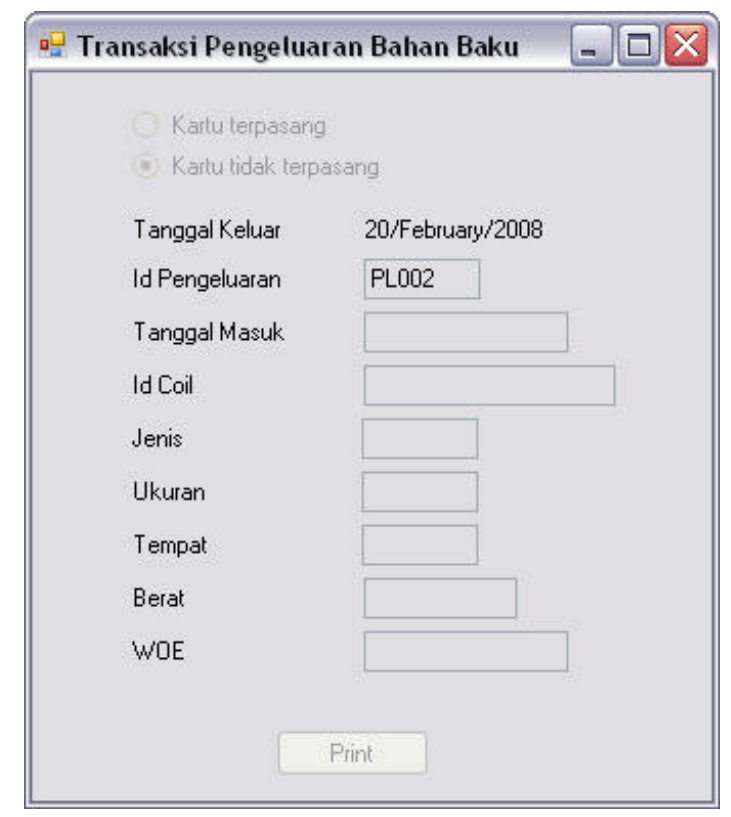

Gambar 6 Rancangan Layar Pengeluaran Bahan Baku 
Data dari form pengeluaran bahan baku dibaca dari RFID card bahan baku. Pengecekan terlebih dahulu kartu terpasang atau tidak terpasang. Tombol 'print' digunakan untuk mencetak data bahan baku yang telah keluar. WOE adalah Bahan baku disusun dalam tumpukan, satu tumpukan terdiri dari 8 coil. Untuk berat dalam satuan kilogram. Work Order Execution (WOE) yang dipakai untuk surat penugasan dalam produksi baut.

\section{Rancangan Layar Periode}

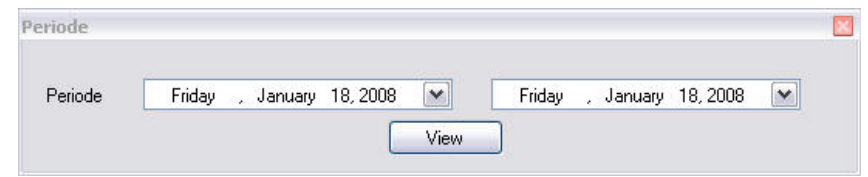

Gambar 7 Rancangan Layar Periode

Form ini untuk memilih periode awal dan periode akhir untuk menampilkan report. Tekan tombol 'view' untuk menampilkan report.

\section{Rancangan Layar Form Report}

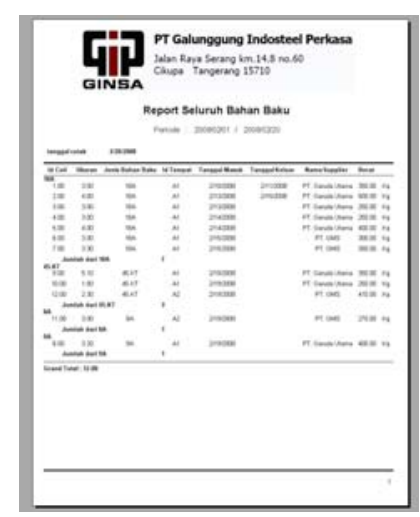

Gambar 8 Rancangan Layar Report

Form ini menampilkan report berdasarkan pilihan report bahan baku yang masuk ke gudang, report stock bahan baku di gudang, dan report bahan baku yang keluar.

\section{Rancangan Layar Pencarian}

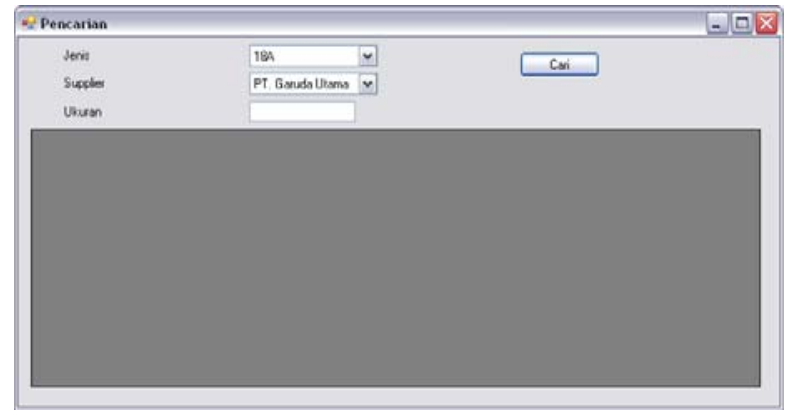

Gambar 9 Rancangan Layar Pencarian 
Form ini menampilkan data bahan baku yang tersimpan dalam database. User memilih berdasarkan jenis, supplier, dan ukuran bahan baku. Terdapat tombol cari untuk menampilkan hasil yang user sudah masukkan.

\section{Rancangan Layar Handheld}

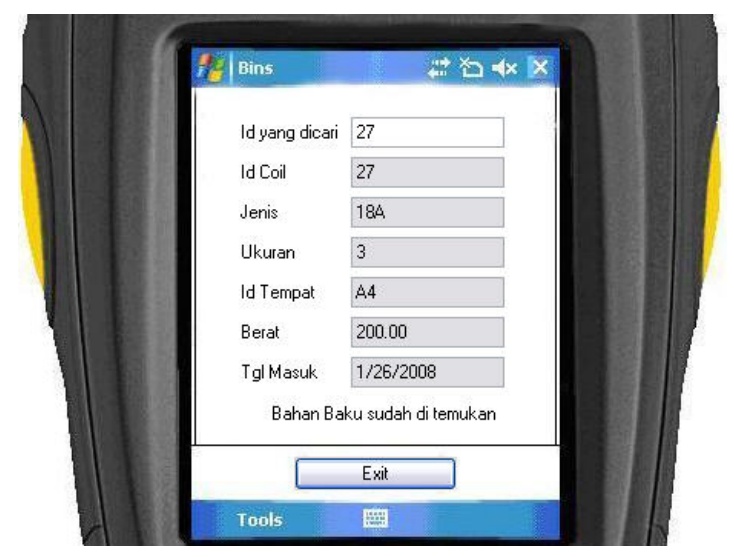

Gambar 10. Rancangan Layar Handheld

Rancangan Layar Handheld ini digunakan pada saat mencari bahan baku di gudang. User dapat memasukkan id yang dicari pada handheld, kemudian men-scan bahan baku yang telah diberi tag RFID.

\section{HASIL DAN PEMBAHASAN}

\section{Evaluasi Waktu}

Evaluasi waktu yang dibutuhkan untuk pencarian bahan baku adalah seperti pada Tabel 1 .

Tabel 1 Evaluasi Waktu

\begin{tabular}{|l|l|}
\hline Sistem yang lama & $\begin{array}{l}\text { Sistem Berbasiskan } \\
\text { RFID }\end{array}$ \\
\hline \pm 50 -60 menit/bahan baku & $\begin{array}{l} \pm 10-15 \quad \text { menit/bahan } \\
\text { baku }\end{array}$ \\
\hline
\end{tabular}

Dengan implementasi sistem aplikasi berbasiskan RFID, waktu untuk pencarian bahan baku dapat dipersingkat dengan cara (1) pencarian bahan baku dengan menggunakan aplikasi, dalam aplikasi pencarian bahan baku dengan fungsi pencarian yang menampilkan data bahan baku serta lokasi bahan baku di gudang; (2) kemudian staf inventori mencari bahan baku di gudang menggunakan Handheld reader. Staf menuju lokasi gudang dan men-scan tag RFID untuk menemukan bahan baku yang tepat.

\section{Estimasi Biaya}

Estimasi biaya adalah sebagai berikut:

Harga rata-rata bahan baku adalah Rp.15000,-/kg.

Berat rata-rata 1 coil bahan baku adalah 500-2000kg. 
Rata-rata pemasukan bahan baku ke gudang per bulan adalah $\pm 25000 \mathrm{~kg}$.

Perhitungan kerusakan bahan baku:

Rata-rata bahan baku rusak 2500kg/bulan, maka:

$$
15.000 \text { x } 2.500=\text { Rp. 37.500.000,-/bulan }
$$

Kerugian dari perusahaan mencapai Rp.37.500.000,-/bulan.

Jika rata-rata kerugian perbulan karena kerusakan bahan baku adalah Rp.37.500.000,-, maka kerugian setahun adalah:

$$
\text { Rp. } 37.500 .000 \text { x } 12=\text { Rp. } 450.000 .000,-/ \text { tahun }
$$

Dengan menggunakan sistem aplikasi inventori berbasiskan RFID ini akan mencegah kerugian perusahaan dengan cara sebagai berikut: (1) bahan baku yang masuk ke gudang terdata dengan baik sehingga semua data bahan baku hingga letak bahan baku dapat diketahui secara jelas; (2) pencarian bahan baku tepat sesuai dengan konsep FIFO. Bahan baku yang pertama kali masuk akan pertama kali keluar digunakan untuk proses produksi. Dari aplikasi akan menampilkan pencarian bahan baku dengan tanggal yang terlama.

Perhitungan biaya investasi menggunakan aplikasi berbasiskan RFID:

\begin{tabular}{|c|c|c|}
\hline \multicolumn{3}{|l|}{ Investasi biaya awal: } \\
\hline Jumlah rata-rata coil sulan & \multicolumn{2}{|c|}{500 coil } \\
\hline Perkiraan harga 1 tag RFID & $\mathrm{Rp}$ & 4,000 \\
\hline Total tag RFID tersedia & $R p$ & 550 \\
\hline Total harga tag RFID & $\mathrm{Rp}$ & $2,200,000$ \\
\hline Perkiraan harga 1 Reader & $R p$ & $5,000,000$ \\
\hline Perkiraan harga 1 Handheld & $R p$ & $10,000,000$ \\
\hline Perkiraan harga 1 Komputer server & $R p$ & $5,000,000$ \\
\hline Perkiraan harga 2 Komputer klien & $R p$ & $8,000,000$ \\
\hline Perkiraan harga 1 switch & $R p$ & 400,000 \\
\hline Total Investasi & $\mathrm{Rp}$ & $30,600,000$ \\
\hline \multicolumn{3}{|c|}{ Perkiraan biaya maintenance per tahun: } \\
\hline Biaya kerusakan tag RFID (2tagibulan) & Rp & 96,000 \\
\hline Biaya maintenance server dan klien & $\mathrm{Rp}$ & $2,000,000$ \\
\hline Total biaya maintenance per tahun & Rp & $2,096,000$ \\
\hline
\end{tabular}

Tabel 2. Evaluasi Biaya

Dengan biaya investasi di atas, akan mengurangi kerugian yang disebabkan akibat kerusakan bahan baku.

\section{SIMPULAN}

Permasalahan pada proses bisnis yang berjalan dapat mengakibatkan kerugian financial dan waktu. Sistem ini dapat mengurangi kerusakan bahan baku yang berkarat dengan menggunakan konsep FIFO dan letak bahan baku yang terdata. Secara tidak langsung dengan mengurangi kerusakan bahan baku, maka kerugian perusahaan yang didapat dari perhitungan mengenai evaluasi biaya dapat dikurangi. Sistem ini memudahkan dan meningkatkan kinerja dalam melakukan pendataan barang masuk, keluar dan juga stok yang masih ada di gudang. Dengan aplikasi berbasiskan teknologi RFID pada sistem ini, maka pencarian bahan baku yang tadinya membutuhkan waktu sekitar 50-60 menit dapat dikurangi menjadi 10-15 menit untuk setiap bahan baku. Perusahaan akan mendapatkan laporan aktual berupa report yang mudah dibuat berdasarkan periode waktu tertentu. 


\section{DAFTAR PUSTAKA}

Indrajit, R. E., \& Djokopranoto, R. (2003). Manajemen Persediaan. Jakarta: PT Gramedia Widiasarana Indonesia.

Wignjosoebroto, S. (2003). Tata Letak Pabrik dan Pemindahan Bahan (3rd ed.). Surabaya: Guna Widya. 